\section{UCDNN}

LIBRARY
University of Connecticut OpenCommons@UConn

June 1982

\title{
In Vitro Cellular Response of Cranial Suture to Tensile Force
}

Wayne B. Hickory

Follow this and additional works at: https://opencommons.uconn.edu/sodm_masters

\section{Recommended Citation}

Hickory, Wayne B., "In Vitro Cellular Response of Cranial Suture to Tensile Force" (1982). SoDM Masters Theses. 53.

https://opencommons.uconn.edu/sodm_masters/53 
IN VITRO CELLULAR RESPONSE OF CRANIAL SUTURE TO TENSILE FORCE

Wayne B. Hickory, M.S., D.M.D.

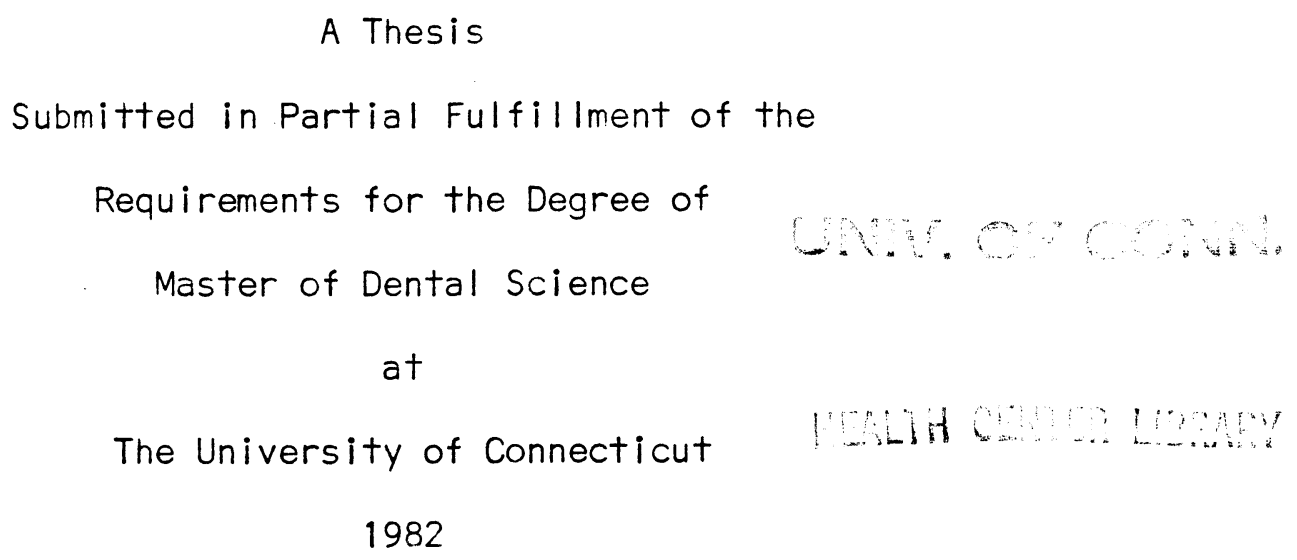




\title{
APPROVAL PAGE
}

\author{
Master of Dental Science Thesis \\ School of Dental Medicine \\ University of Connecticut Health Center
}

IN VITRO CELLULAR RESPONSE

OF CRANIAL SUTURE

TO TENSILE FORCE

Presented by

Wayne B. Hickory, M.S., D.M.D.

Major Advisor Raundna 1 aude Ravindra Nanda

Professor, Department of Orthodontics

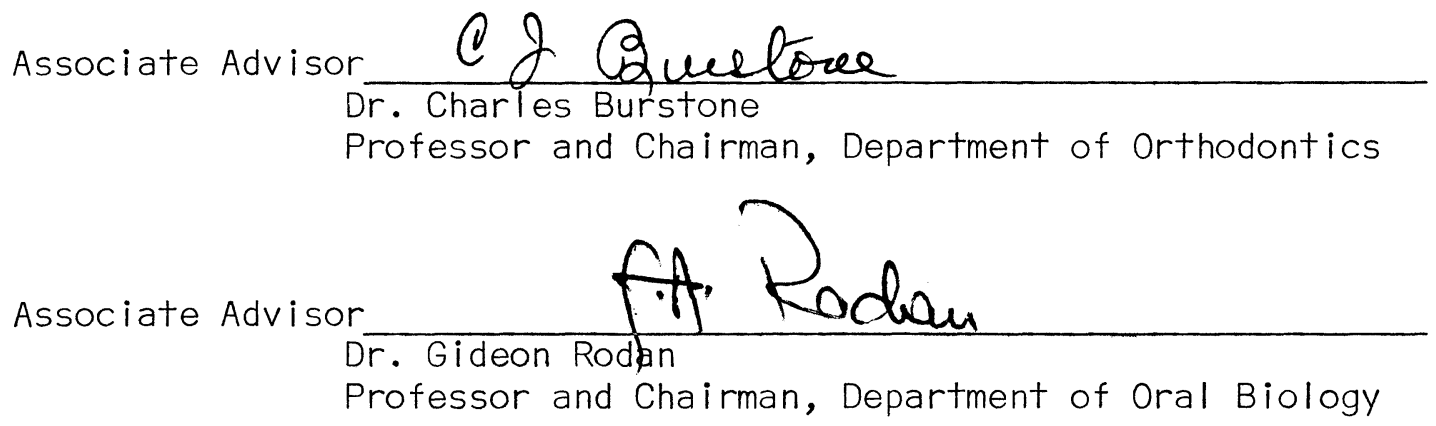


TABLE OF CONTENTS

$\underline{\text { Page }}$

Introduction 1

Literature Review 2

Manuscript submitted to

American Journal of Orthodontics

Introduction

Materials and Methods

Results

Discussion

22

References to manuscript

48

Conclusion

50

References 


\section{LIST OF TABLES}

Page

1 - Suture width as a function of force magnitude and duration

11 - Strain as a function of force magnitude and duration

111 - Effect of force magnitude and duration on labelling index 
- Two-day old rat cranium

2 - Spring calibration

31

3 - Activated springs 33

4 - Explants in organ culture 35

5 - Suture-bone interface 37

6,7 - Explants with high labelling index 39

8 - Explant with low labelling index 41

9 - Labelling index as a function of strain 43

10 - Fibroblasts 45

11 - Mesenchymal tissue 47 


\section{INTRODUCTION}

The target tissue of facial orthopedics is facial sutures. Currently design and application of dentofacial orthopedic appliances are not based on an understanding of suture tissue response to force system components (magnitude, duration, direction, constancy). Thus, it is of interest to identify how the variables of a force will influence the response of this tissue.

Clinical and in vivo studies have been limited by the complexity of the craniofacial complex. The variables of the force have not been controlled. Additionally, the biologic response has not been measured.

The goal of this study is to establish a simple in vitro model which will allow for control of all force variables and measurement of suture response. Specifically, tritiated thymidine uptake will be measured as tensile force magnitude or duration is varied, while controlling all other variables of the force system. 


\section{LITERATURE REVIEW}

SUTURE MORPHOLOGY

Fitrous connective tissue joints (syndesmoses) form the articulations between all the bones in the craniofacial complex, except for the cranial base synchrondoses and temporomandibular joints. The ristological organization of this tissue has been described as consisting of a number of zones, as reviewed by Enlow (1968) and Fersson (1973).

Weinmann and Sicher (1965) presented a three-layer view of suture morphology: a middle zone and two peripheral zones adjoining the two bone surfaces. The middle zone is highly cellular and contains irregularly arranged immature collagen. The peripheral zones are composed of dense connective tissue the fibers of which thicken as they approach the bo le surface which they enter as Sharpey's fibers.

Pritchard, Scott and Girgis (1956) described a five-layer concept of the suture. As in the three-layered view the central layer was described as having irregularly arranged immature fiber bundles. Additionally, the central area was noted to be highly vascular, containing sinusoidal vessels. Bilateral to the central layer two peripheral layers were described: a cambial (cellular) subdivision of the periosteum adjoining the bone surface and a fibrous subdivision of the periosteum next to the middle layer. The cambial layers, demonstrating many mitotic figures, were recognized to be the sutural growth sites. While Pritchard et al., found the five-layer picture in the non-growing adult suture, others (Enlow, 1968 and Lathar, 1971) 
have viewed the adult suture as a more homogeneous structure composed of coarse collagenous fibers with fewer cells and blood vessels.

The suture and the periodontal ligament (PDL) have some structural similarities, since both are connective tissue membranes which join two adjacent calcified tissues by collagen fibers. Both are highly responsive to applied forces and possess mechanisms for remodelling which may be similar, as will be discussed later. Enlow (1968) claimed the suture and PDL allow for formation and reorganization of fibers in an intermediate zone of immature collagen and in the outer cambial layers. However, an intermediate plexus of the PDL where a loose interrelationship of fibers was described to occur by Sicher (1954) may not exist according to more recent data indicating that the principal fibers of the PDL extend unerupted from cementum to bone (Zwarych and Quigley, 1965; Ciancio et al., 1967; and Shackleford, 1971).

RESPONSE OF CONNECTIVE TISSUE COMPONENTS TO FORCE

Most studies of the response of connective tissue to tensile force have been on the periodontal ligament $(\mathrm{PDL})$ and related to clinical interest in orthodontic tooth movement. Many of these findings have applicability to craniofacial sutures since the cellular and extracellular components of the PDL and sutures are similar and both respond similarly to applied forces (e.g., cell proliferation, collagen synthesis, bone formation).

Bone formation has been shown to be a response in areas subjected 
to tension resulting from orthodontic force (Macapanpan et al., 1954 Waldo and Rothblatt 1954, Zaki and Van Huysen, 1963). Proliferation of local progenitor cells precedes new bone formation as seen by tritiated thymidine kinetic studies of rat PDL cells subjected to tension (Baumrind and Buck, 1970; Roberts and Jee 1974; Yee et al., 1976; Roberts and Chase, 1977).

The proliferative capability of the PDL and sutures appears related to their ability to respond to functional demands (forces). Ultrastructural studies by Yee (1976) have shown that PDL fibroblasts are multifunctional cells, central to the responsiveness of the PDL, involved in the synthesis and degradation collagen, as well as providing a progenitor pool of cells which proliferate in response to orthodontic force.

Two waves of orthodontially stimulated mitoses have been observed in the PDL of the rat: the first at 9 hours after injection of $3 \mathrm{H}$-thymide and the second at 34 hours after ${ }^{3} \mathrm{H}$-thymidine injection (Roberts et al., 1974). Roberts further noted that of the PDL fibroblasts initially labelled at 8 or 27 hours after stimulation only about $17 \%$ went through a second mitosis, whereas, of those labelled at 36 hours about $34 \%$ went through a second mitosis. This suggested that cells responding early become secretory fibroblasts repairing forn fibres and synthesizing new ones, whereas, cells responding later are more representative of stem cells which would for example supply the osteoblasts for the increased bone apposition.

Although the changes incident to orthodontic forces in the PDL and adjacent hard tissues have been well described histologically (Reitan, 
1975), the mechanism of the ligament remodelling process is not clearly understood. As seen by ${ }^{3} \mathrm{H}$-prol ine autoradiography, the PDL has a very high rate of collagen turnover, even when not subjected to orthodontic forces (e.g., Stallard, 1963; Carneiro and Morase deFava, 1965; Anderson, 1967; and Skougaard et al., 1970; Kameyama, 1973 and 1975). Thirty minutes after applying force to rat molars, Crumley (1964) noted increased accumulation of $3 \mathrm{H}$-proline as compared to controls. Diaz (1978) demonstrated a reduction of $3 \mathrm{H}$-proline removal on the tension side of the ligament.

The nature of the response of connective tissue to force has many unclear aspects. For example, the metabolic response may be a specific increase in collagen synthesis or decreased degradation or a generalized increase in protein synthesis. Even less clear is the mechanism by which these biochemical responses are triggered by mechanical stimuli (Harell et al., 1977).

RESPONSE OF SUTURES TO TENSILE FORCES GENERATED DURING GROWTH

The fibrous joints of the craniofacial complex including the periodontal ligament are very responsive to applied forces. This response is important to the growth process, as well as being the basis for the effectiveness of externally applied forces of orthodontics and facial orthopedics. The craniofacial sutures have long been recognized as important to the growth process. Craniofacial sutures are subjected to tension caused by the growth of other tissues. Sutures allow for adjustments in the spacial relationships of bones (Baer, 1954 and Pritchard et al., 1956). 
The mechanism by which growth occurs at sutures has been a subject of some debate. It has been proposed that the force for the separation of bones at the suture is generated from within the suture. The expansile force of cellular proliferation within the sutural tissue has been suggested to be the basis of bone separation (Moore, 1949; Weinmann and Sicher 1955; and Sicher, 1965). Prahl (1968) has proposed that a separating force is provided by the suture fibers.

The contrasting view, for which there is more support, states that sutures play a passive role, growing only in response to the expanding bones. According to this theory the response of sutures to growth would be similar to their response to forces resulting from orthodontic or orthopedic appliances. According to Moss' functional matrix theory (Moss 1962) craniofacial sutures are in an environment of various forces, including functional forces (e.g., mastication, deglutition and respiration) and forces from tissue growth (most notably the expansile force caused by the growth of the brain). The dependence of sutural growth on external forces has been demonstrated by isolating craniofacial sutures from extra-sutural forces, by tissue culture or transplantation, to non-growing sites which results in termination of separation of the bones (Watanabe et al., 1957; Moss, 1957; Prahl, 1968 and Lewin and Irwing, 1970). Engdahl et al., (1978), showed that when a suture is transplanted to a site where growth is rapid and forces exist, its growth may be greater than normal, emphasizing the adaptive nature of the suture to the milieu of forces in which it is placed. 
ORTHOPEDIC CHANGES FROM FORCES APPLIED TO SUTURES

Orthodontics involves correction of skeletal disharmonies as well as dental malocclusions. A common skeletal discrepancy is a mandible which shows an inadequate amount of anterior growth relative to its opposing maxilla. A routine approach to treating this situation is by passive modification of growth of the facial bones by using external forces. In the case of the mandible posteriorly positioned relative to the maxilla, this would involve a distal force applied to the maxilla. However, recently clinical and experimental studies have proposed active modification of the spacial position of facial bones by using extraoral forces to accelerate growth of selected skeletal areas.

Since, as described above, sutures respond to forces, this response can be evoked by orthodontic or orthopedic appliances. Tension is applied to sutures during certain orthodontic procedures such as palatal expansion and maxillary protraction. When the skeletal base of the maxillary teeth is narrow, an appliance with anchorage on the maxillary posterior teeth is activated in the transverse dimension to apply pressure to these teeth. This creates tension in the midpalatal suture and other structures in the craniofacial complex and results in separation of the palatal bones. The remodeling changes caused by tension or compression have been the subject of numerous studies, but the extent to which this is a gradient response, dependent on parameters of the force system such as force magnitude or duration is not clear.

The forces produced during palatal expansion have been measured 
using strain gauges (Isaacson 1964, 1965). Isaacson reported heavy forces resulted in minimal movement of the teeth, to which the force was applied, and maximal skeletal changes. Since the force value did not decrease when the midpalatal suture opened, I saacson concluded that the resistance to expansion is in the total ity of the craniofacial complex. The complex interrelationships of the facial skeletal components imply that forces applied at any one suture would result in forces distributed throughout the complex. Although the literature is replete with studies on palatal expansion, the uncontrolled variables in both the force system and the biologic system make it impossible to accurately relate any change in the force system to any particular response of the tissue. Many of these studies have been of value in analyzing the result of a force on the totality of the craniofacial complex, which is of clinical interest. Study of suture response to force must distinguish it from its complicated environment of attachments to other structures which dissipate any applied force. While in vivo studies of palatal expansion have not estimated the strain in the suture, these studies have provided information regarding the nature of response as viewed histologically. A series of events have been described in the separation of this suture: proliferation and reorganization of the tissue, bone resorption in areas of interdigitation, followed by bone deposition which eventually restores the suture morphology. (Murray and Cleall, 1971).

Studies of the response of facial sutures to a protraction force applied to the maxilla have also provided a description of suture 
response to tension (Kambara, 1977, Nanda 1978, and Jackson et al., 1979). Histologically, the capsular zone of the suture appeared highly vascular, fiber bundles were stretched in the direction of the applied force and bone apposition was noted in areas of suture stretching. An analysis of the zygomaticomaxillary suture relative to the protraction force system demonstrated a very complicated response as some areas of the suture were in compression while other areas were under tension (Nanda, 1978). This results from the existence of rotational component of the protraction force system and from the complicated three-dimensional anatomy of the suture. Thus, in vivo studies have had limitations in relating the force system to the suture response due to the distribution of the force to remote sites and the complexity of the force system along microscopically and macroscopically tortuous paths of the craniofacial sutures. One study partially overcame these obstacles by inserting legs of a helical spring directly into the parietal bones of guinea pigs to separate the relatively simple interparietal suture (Hinrichsen and Storey, 1968). However, they made no attempt to study the effect of any of the force variables (e.g. force magnitude or duration) on the response of the tissue.

\section{IN VITRO STUDIES}

The difficulty of studying the relation of craniofacial suture response to force system variables in vivo would suggest the value of developing an in vitro model. The only reports in the literature of force applied to a suture in vitro has been by Meikle et. al., (1979 
and 1980). These studies did not analyze any variation in the parameters of the force system, but did establish an in vitro model (cranial sutures of new born rabbits) and presented findings regarding the response of suture tissue to tensile stress at the molecular level. A tensile stress of 30 grams applied in vitro to cranial sutures of new born rabbits resulted in a significant (twofold) increase in the incorporation of $3 \mathrm{H}$-leucine and $3 \mathrm{H}$-proline into suture protein, including collagen (Meikle, et al., 1979).

The same system demonstrated increases in collagenase, gelatinase, neutral metal loproteinase 111 and an inhibitor which complexed with the increased quantities of enzyme such that there was no increased degradation of structural proteins (Meikle, et al., 1980). The mechanically activated fibroblasts of the suture appear unable to selectively synthesize structural proteins, but instead respond with a generalized stimulation of protein synthesis. Meikle, et al., (1980) also reported a $87 \%$ increase in the incorporation of $3_{H}$-thymidine into DNA as an early (24 hours) response of suture to tensile force. Thus, some measurable molecular responses of the suture have been identified. 
IN VITRO CELLULAR RESPONSE OF CRANIAL

SUTURE TO TENS ILE FORCE

Wayne Hickory, DMD, MS, MDS*

Ravindra Nanda, BDS, MDS, PhD**

Farmington, CT

This study was supported by

National Research Service Award DE005202

from the National Institutes of

Health National Institute of Dental Research

*Department of Orthodontics, School of Dental Medicine University of Connecticut, Farmington, CT. 06032 and Department of Orthodontics, School of Dentistry Free University, P.O. Box 7161

1007 MC Amsterdam, Holland

**Professor, Department of Orthodontics

School of Dental Medicine

University of Connecticut

Farmington, CT. 06032 
Contemporary orthodontics includes treatment of skeletal disharmonies as well as dental malocclusions. To correct skeletal problems, dentofacial orthopedic appliances usually apply pressure or tension to the maxillo-facial sutures. A common mode of treatment is the use of distally directed headgear to displace the maxilla posteriorly or to inhibit its anterior growth. There is increasing interest in the use of protraction headgear to applying an anteriorly directed tensile force to correct midface deficiency. In the transverse dimension, tension is frequently applied to expand the midpalatal suture in cases presenting with a narrow skeletal base for the maxillary dentition.

There are many questions regarding the effectiveness of appliances aimed at changing facial form as well as questions regarding the proper prescription of these appliances in terms of force magnitude, duration, constancy, point of application and direction. Clinical and animal studies have provided some information. However, development of a rationale for appliance design is ideally based on an understanding of the nature of the biologic response of the target tissues to specific force system parameters.

An accurate study of the biologic response of suture to a force system requires that all aspects of the force system be defined including force magnitude, duration, direction and constancy. Additionally, a measurable biologic response should be monitored. The goal is to predict the response and to generalize basic findings from one model to another. This is possible only when the large number of variables present clinically are controlled. While in vivo 
experimental and clinical reports have provided limited information about the response to dentofacial orthopedic appliances, a clear study of suture response to specific changes in a force system is difficult through these investigative approaches. Force applied to a suture is dissipated throughout the craniofacial complex. Isaacson, in measuring forces generated during palatal expansion, noted that the force value did not decrease when the midpalatal suture opened, indicating that the bulk of the resistance is in other areas of the craniofacial complex. Although studies of palatal expansion have not estimated the strain in the suture itself, these studies have provided information regarding the nature of response as viewed histologically. A series of events have been described in the separation of this suture: proliferation and reorganization of the tissue, bone resorption in areas of interdigitation, followed by bone deposition which eventually restore the suture morphology. 2

In vivo studies are further complicated by the complex threedimensional macroscopic and microscopic anatomy of craniofacial sutures. Nanda ${ }^{3}$ described the complicated response of the zygomaticomaxillary suture relative to a protraction force system in monkeys. Due to the interdigitations and general complexity of the suture, some areas of the suture were subjected to compression while others were experiencing tension as a result of protraction force applied to the maxilla. The problems of complexity of suture anatomy and resistance offered by remote tissues were partially overcome by Hinrichsen and Storey 4 by inserting helical springs directly into the parietal bones of guinea pigs. However, there was no study of how 
changes of force system variables effect the response of the tissue. Thus, while a number of in vivo studies have provided illuminating descriptions of suture response to tension, 3-6 a more simplified model is needed to directly evaluate the biologic response of suture connective tissue to changes in an applied force system.

While in vivo studies have direct clinical implications, the answers to basic questions regarding the biologic response to applied forces requires greater control of variables. Meikle, et al., have reported an in vitro model for studying tensile force applied to rabbit cranial sutures. However, their studies did not analyze the effect of varying different parameters of the force system. To accurately study the response of sutures to tension both the force system and biologic response must be clearly defined and measurable. The calvaria organ culture model proposed in this study allows for the precise application of a force system with all its components defined. Selection of force magnitude and duration for extra-oral appliances is largely a matter of clinical judgment. This study has focused on force magnitude and duration as variables of the force system.

Sutures and periodontal ligament are composed of similar structural components. Force applied to these tissues evokes similar responses including cell proliferation, collagen synthesis and bone formation. Cell proliferation has been shown to be an early response to tension applied to the periodontal 1 igament $9,10,11,12$ and sutures. 8 Also, cell proliferation is of interest in the present study due to the tensile nature of the force and the simple topo- 
graphy of the suture in the model system to be described.

Thus, the objective of this study is to relate changes in the magnitude and duration of a tensile force to cell proliferation in a cranial suture, as measured by the percentage of cells incorporating tritiated thymidine. 
MATERIALS AND METHODS

A simple model to apply tensile stress to rat cranial sutures in organ culture was devised. Two-day old Charles River rats were killed by decapitation. Under aseptic conditions the cranial bones were defleshed (Fig. 1). An explant of standardized size (5 mm. of suture length) was then dissected and placed in F-12 culture media (Gibco) until all the explants were ready for application of the spring appliances. The explant consisted of the parietal bones and the intervening midsaggital suture.

Helical springs were designed to apply a constant light force which could be accurately measured. Helical springs were fabricated from 0.010 inch stainless steel orthodontic wire. Six helical turns and $6 \mathrm{~cm}$. long legs of the springs provided a low load deflection rate, facilitating accurate spring calibration and force constancy. The springs were calibrated to deliver $0,0.2$ or 0.6 grams of force when closed to $7 \mathrm{~mm}$., which was the amount of spring closure used when the springs were applied to the sutures. The springs were calibrated on a top-loading balance as illustrated in figure 2 . The amount of activation placed in the springs for each of the three force magnitudes is shown in figure 3 .

After the springs were activated, as described above, they were taped to glass slabs while closed to $7 \mathrm{~mm}$. of opening between the arms. The springs were then autoclaved in an activated state. The springs were then ready for easy application to the explants under sterile conditions. The pointed ends of the spring arms were used to perforate the parietal bones on each side of the suture to provide a 
tensile force. Perforation at the middle of each bone was important to provide even separation without rotation. Thus, the point of application, force direction, magnitude constancy and duration were controlled. The explants with attached springs were then incubated for up to 48 hours as described below.

F-12 culture media (Gibco) was used with the addition of $10 \%$ fetal bovine serum and $1 \%$ antibiotic-antimycotic. Cultures were incubated at $37^{\circ} \mathrm{C}$. in an environment of $95 \%$ air $/ 5 \%$ carbon dioxide.

Forces were applied from 1 to 48 hours with a force duration group observed at least every three hours. For each force duration group, six explants were incubated - two for each force magnitude.

Cell proliferation was measured by determining the percentage of dividing vs. non-dividing cells using autoradiography to assess incorporation of tritiated thymidine into DNA. For the last hour of incubation and force application tritiated thymidine (specific activity $20 \mathrm{Ci} / \mathrm{M}$ mole) was added to the media so as to have a concentration of labelled thymide of $5 \mu \mathrm{Ci} / \mathrm{ml}$.

At the end of each incubation period explants were removed from culture, fixed, decalcified, embedded in paraffin and serially sectioned coronally at $5 \mu \mathrm{m}$. The sections were then prepared for autoradiography by coating the slides with Kodak NTB-2 emulsion by the dipping method followed by exposure in the dark for 3 weeks. The sections were then developed and stained with hematoxylin and eosin. The labelling index was determined by counting the percentage of cells labelled in a population of 300 cells in the mid-suture area of four slides from each explant. During counting the identity of the 
sections were masked.

The mid-suture area (in the interior-superior dimension) was identified as those sections with continuous connective tissue between the two parietal bones. Within this area the middle eight sections were identified and every other one was counted. In the anterior-posterior dimension the middle of the suture was identified using the grid place on the screen of a projection microscope. Approximately 100 cells fill the field. The middle field and about two fields on either side of the middle field were counted until a total of 300 cells was reached. Thus, 300 cells were counted in each of four sections for each of the three force levels for each time period. Differences between force magnitude groups and force duration groups were evaluated for significance by analysis of variance. 
RESULTS

Control explants, which had springs exerting no tensile force, showed no signs of stretching. The suture width remained constant $(0.7 \mathrm{~mm}$.) for all time periods observed from 1 to 54 hours. Suture tissue subjected to $0.2 \mathrm{~g}$. of tension displayed a moderate amount of stretching as seen in Table 1. The first increase in width $(0.2 \mathrm{~mm}$.) was noted after 9 hours of $0.2 \mathrm{~g}$. tensile force. An increase in suture width of $0.5 \mathrm{~mm}$. was recorded after 22 hours. More rapid and larger bone displacement was seen with $0.6 \mathrm{~g}$. of tension (Table 1). Displacement was noticeable by 3 hours and by 22 hours $2.0 \mathrm{~mm}$. of stretching had occurred. The change in suture width was generally uniform throughout the length of the suture due to the placement of the spring legs in the middle of the parietal bones. In several instances when the legs were not placed in the middle of bones some rotation occurred and stretching was greater at one end. Measuring at the middle of the suture minimized the effect of this variation. Displacement is also expressed as strain (Table 2) calculated by dividing displacement by original width. Strain can be more easily compared to results in other models in contrast to absolute displacement.

Although thymidine uptake was seen beyond 32 hours, signs of cell degeneration were noted as early as 28 hours. Because the twoday-old rat calvaria explant is a relatively mature tissue for organ culture, duration of vitality is limited. Thus, thymidine uptake results are presented only to 22 hours. 
The middle area of the suture, in which total cells and labelled cells were counted, is composed largely of undifferentiated mesenchymal cells. These cells are characteristically large with spheroid nuclei and non-distinct intercellular membranes. This is also a proliferative tissue as evidenced by the high percentage of dividing cells initially with or without application of force (Table 3 ).

In some instances a group or region of cells had a high density of label uptake. Frequently the area adjacent to the parietal bones showed a high incidence of labelled cells as suggested in figure 5. Such regional variation was controlled by counting in the middle of the suture as described in the methods.

Mean labelling indicies for various force durations and magnitudes are recorded in Table 3. Figures 6 and 7 are representative of explants with a relatively high percentage of cells incorporating labelled thymidine as seen after 5 hours of incubation with $0.2 \mathrm{~g}$. of tensile force. A lower labelling index is illustrated after nine hours with $0.6 \mathrm{~g}$. of tensile force in Figure 8 . Within each force duration group the $0.2 \mathrm{~g}$. force was associated with a greater percentage of cells incorporating tritiated thymidine. Analysis of variance indicates the differences between groups is significant beyond the 0.01 level.

Figure 9 illustrates the relation of strain to the labelling index for several duration groups (9, 11 and 22 hours). Although only several points are available, it suggests that within a given force duration group increasing strain increases thymidine uptake to some point, after which diminishing uptake occurs with increasing 
strain.

With increasing force duration the suture explants subjected to tensile force had more fibroblast-like cells (Fig. 10) in contrast to the undifferentiated messenchymal cells which predominated earlier (Fig. 11). The fibroblasts are more fusiform and are oriented perpendicular to the bone-suture interface. An abundance of extracellular matrix components is evident. By contrast the suture explants not subjected to force remain largely epitheloid in the midsuture area. As seen in figure 10, these cells are more spheroid and lack distinct cell membranes. The cell density of the messenchymal cells is such that the orientation of extracellular components is not evident. 


\section{DISCUSSION}

A major focus of this study has been to control the various aspects of a tensile force system. The spring-explant model provided control of each of the variables of the force system. The accuracy of measuring the force magnitude was enhanced by an appliance design having a low load deflection rate. Also, the low load deflection rate of approximately 0.1 gram per centimeter provided force constancy since the spring opened no more than $3 \mathrm{~mm}$. during incubation. Many studies 13,14,15,16 of connective tissue response to force have used appliances with a high load deflection rate, such as a rubber wedge or elastic placed between teeth to produce tension in the periodontal ligament. This yields a high initial force which falls rapidly with time. In many previous experimental designs force magnitude was neither constant nor measured.

No biologically based rationale has been proposed for selection of force magnitude in dentofacial orthopedics. Badel1 17 expressed force magnitude as percentage of body weight for comparison of human and animal studies. Although there was no scientific explanation for the comparison to body weight, there may be some correlation of body weight to the area of the suture tissue. Strain (displacement/ original width) provides more meaningful comparative information than applied force since it takes into account the properties of the tissue. The most appropriate measurement is stress derived by dividing magnitude by cross sectional area. Future studies are planned to measure cross sectional area of the area of the sutures in the 
explants. This will allow for comparison of biologic response to stress rather than magnitude which has less meaning when taken out of the context of a given model.

In previous in vivo studies force magnitude has been measured only prior to its application to the craniofacial complex. However, this force is dissipated to other structures remote from the suture of interest. This has prevented the determination of an optimal force system to effect a given orthopedic change. The calvaria culture model presented lacks resistance from structures outside the suture. Thus, the force applied to the parietal bones equalled the force applied to the suture tissue.

Nanda ${ }^{3}$ applied a protraction force system to monkeys in which all the force variables were measured. Although the force system was controlled, the complexity of the anatomy of the sutures made it difficult to correlate force variables with suture response. The simplicity of the suture explant described in the present study allows for a uniform application of the tensile force and a direct relation between biologic response and variation in the force.

In addition to maxillary protraction, palatal expansion and tooth movement have provided in vivo experimental models for the study of connective tissue response to tension. Although relationships between force variables and biologic response have not been clear in in vivo studies, some basic information of how connective tissue responds to tension has been provided.

$\mathrm{Yee}^{18}$ noted increased mitotic cells in PDL subjected to stress at the earliest time of observation, which was 24 hours. This 
finding suggested the PDL fibroblasts may be multifunctional cells capable of generating new cells in response to stress as well as being functional fibroblasts. The findings presented confirm an early response. The similar structure and response to force of PDL and craniofacial sutures is consistent with the reports of others. $4,5,19,20$ An early metabolic response of sutures to force in vitro was also shown by Meikle, et al., 7 who demonstrated increased protein synthesis in stressed suture cells at the earliest time period observed ( 6 hours). In the present study differences in tissue response were shown within the first few hours of force application.

The finding of greater tritiated thymidine uptake in the intermediate $(0.2 \mathrm{~g}$.$) force groups in comparison to the 0.6 \mathrm{~g}$. or $0 \mathrm{~g}$. groups suggests that tension increases the percentage of dividing cells, but at some point higher force magnitude may decrease the cell proliferation response. Another possible explanation for the increased uptake of tritiated thymidine is that the stretching of the tissue caused increased perfusion of nutrients into the tissue. The finding of lower uptake by the $0.6 \mathrm{~g}$. in contrast to $0.2 \mathrm{~g}$. supports the statement by Meikle et al., ${ }^{7}$ that the effect of stretching is probably not mediated by increased diffusion of nutrients into the tissue. Furthermore, there is much evidence suggesting that mechanical perturbation of the plasma membrane can cause biochemical changes within cells. $21,22,23$

The lower percentage of cells incorporating thymidine in the higher force magnitude group is consistent with the histologic 
observations. A larger portion of fibroblast-like cells were noted with higher-force magnitude at the later time periods. While the fusiform appearance of these cells may be partially due to physical stretching, it was suggested that some differentiation of immature messenchymal cells to fibroblasts had occurred in culture. The more mature fibroblasts would be expected to incorporate less thymidine in contrast to the messenchymal cells for which proliferation is a major function.

Further studies are planned to identify variations of the response in different regions of the suture. This study chose the middle area of the suture in both the anterior-posterior and mediallateral dimension. By selecting the middle area anterior-posteriorly the effects of any rotation were minimized. Medial-lateral differences would be of interest in view of the proposed zones or layers of the suture and their different functions. 24,25

The explant-spring model presented holds potential for studying the cells kinetics of connective tissue to force which may be applicable to PDL as well as facial sutures. Additionally, metabolic influences (e.g. nutrition or hormones) on the response of sutures to force could be studied in the future through modification of the culture media. 
TABLE ।

SUTURE WIDTH AS A FUNCTION OF FORCE MAGNITUDE AND DURATION

$$
\text { FORCE MAGNITUDE (GRAMS) }
$$

$$
\begin{array}{lll}
0 & 0.2 & 0.6
\end{array}
$$

$\begin{array}{clll}\begin{array}{l}\text { Duration } \\ \text { (hours) }\end{array} & 0.7 \mathrm{~mm} * & 0.7 \mathrm{~mm} . & 0.7 \mathrm{~mm} . \\ 1 & 0.7 & 0.7 & 0.9 \\ 3 & 0.7 & 0.7 & 1.1 \\ 5 & 0.7 & 0.9 & 1.4 \\ 9 & 0.7 & 1.0 & 1.8 \\ 11 & 0.7 & 1.2 & 2.7 \\ 22 & 0.7 & 1.2 & 2.9 \\ 32 & 0.7 & 1.4 & 3.8 \\ 54 & & & \end{array}$

* Mean values based on photographs of three explants. 
TABLE 2

STRAIN IN SUTURE AS A FUNCTION OF FORCE MAGNITUDE AND DURATION

$$
\text { FORCE MAGNITUDE (GRAMS) }
$$
0
0.2
0.6

Duration

(Hours)

$\begin{array}{llll}1 & 1.0 * & 1.0 & 1.0 \\ 3 & 1.0 & 1.0 & 1.3 \\ 5 & 1.0 & 1.0 & 1.6 \\ 9 & 1.0 & 1.3 & 2.0 \\ 11 & 1.0 & 1.4 & 2.6 \\ 22 & 1.0 & 1.7 & 3.5 \\ 32 & 1.0 & 1.7 & 4.1 \\ 54 & 1.0 & 2.0 & 5.4\end{array}$

* Strain Units - change in width (m.)/initial width 
TABLE 3

EFFECT OF FORCE MAGNITUDE AND DURATION ON LABELLING INDEX

FORCE MAGNITUDE (GRAMS)
0
0.2
0.6

\begin{abstract}
Duration
(hours)
\end{abstract}

$\begin{array}{cccc}1 & 9.2 \% * & 11.2 \% & 5.9 \% \\ 3 & 8.8 & 19.3 & 12.0 \\ 5 & 10.0 & 15.7 & 9.5 \\ 9 & 5.4 & 6.6 & 4.6 \\ 11 & 3.4 & 8.8 & 6.9 \\ 22 & 9.8 & 12.7 & 6.5\end{array}$

* Labelled cells as a percentage of total cells.

Analysis of variance

$\begin{array}{lccccc}\text { Main Effect } & \text { df } & \text { ms } & \text { df } & F & P \\ \text { Time } & 5 & .0176 & 87 & 94.4 & <.001 \\ \text { Force } & 2 & .026 & 87 & 139.1 & <.001 \\ \text { Interaction } & & & & & \\ \text { Time-Force } & 10 & .0025 & 87 & 13.4 & <.001 \\ \text { Withincells } & 87 & .0002 & & & \end{array}$




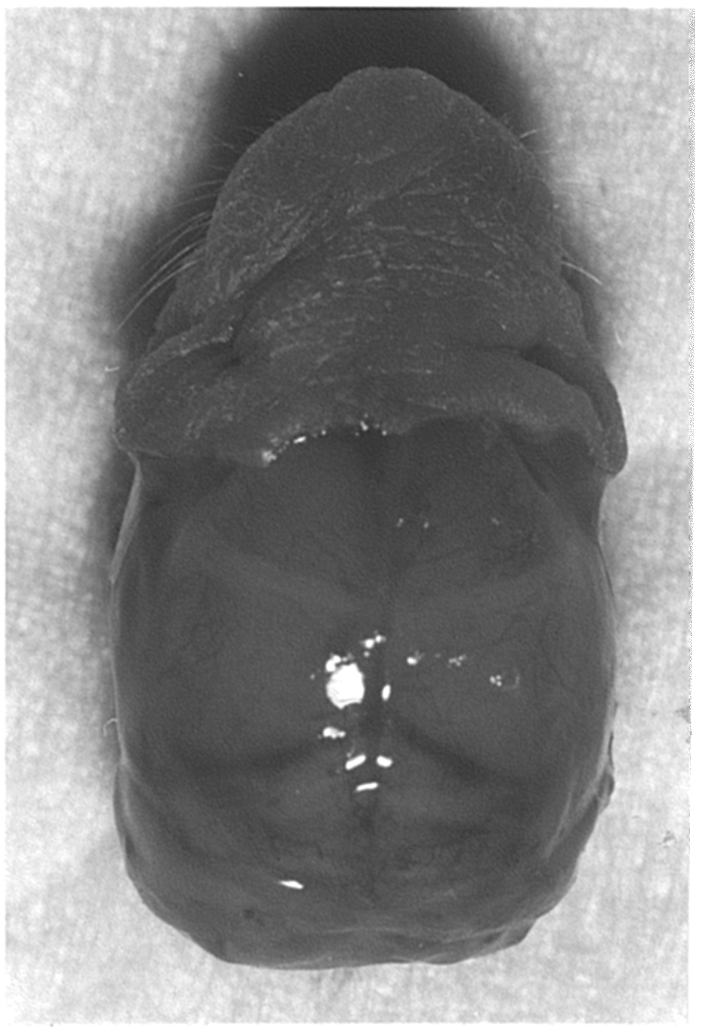


Figure 1. Partially defleshed cranium of two-day old rat showing midsaggital suture and parietal bones. 


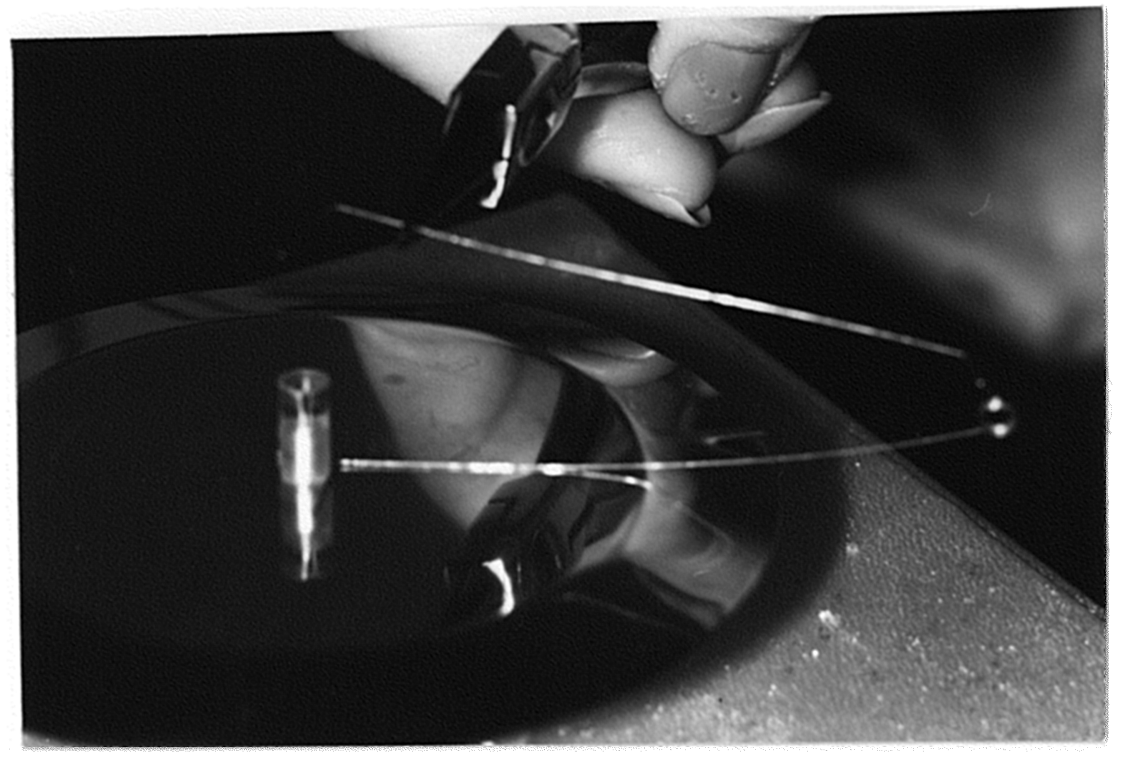

$2 \mathrm{~A}$

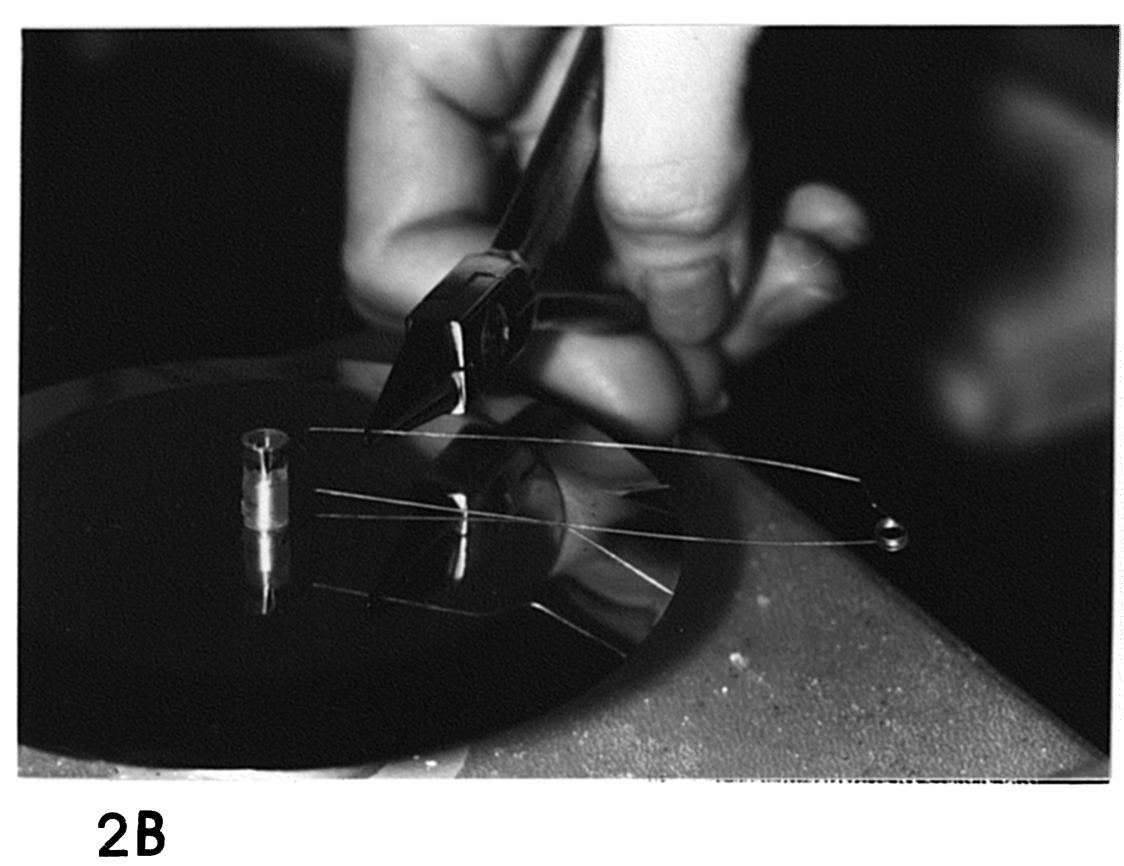




Figure 2. Spring activatons were measured by resting
one leg of a helical spring on the balance
pan of a top-loading balance $(2 \mathrm{~A})$ and
bringing the other leg to $7 \mathrm{~mm}$. of closure
(2B). The electronic balance then reach
the tensile force delivered by the spring
when it is applied with $7 \mathrm{~mm}$. of closure.
A post with mm. markings was placed in the
center of the pan to measure the $7 \mathrm{~mm}$. of
closure.




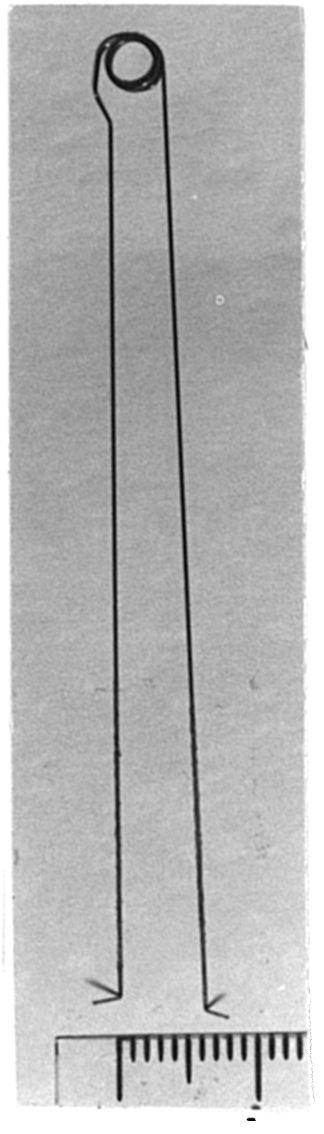

A

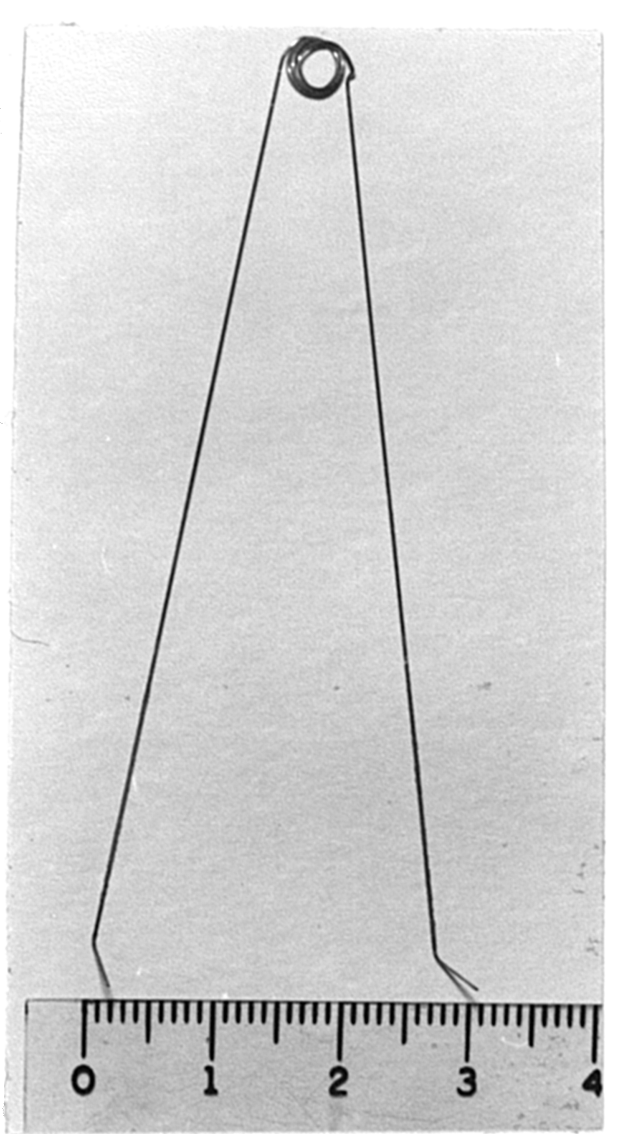

B

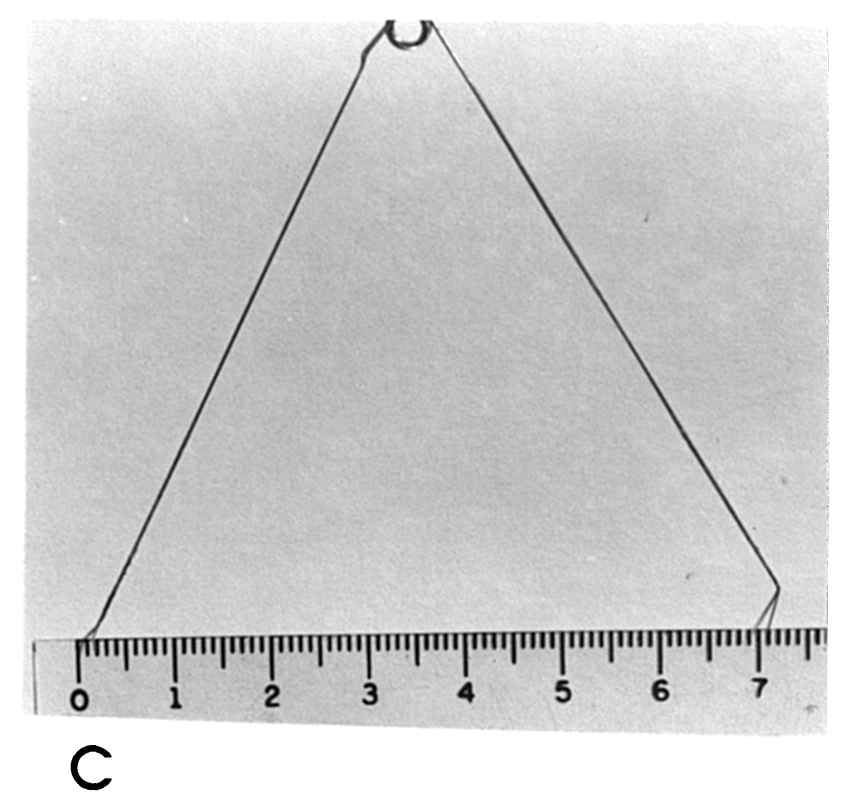


Figure 3. Springs are shown after calibration to deliver

$0,0.2$ or 0.6 grams of tensile force when

closed to $7 \mathrm{~mm}$. Spring $A$ is passive at $7 \mathrm{~mm}$.

of closure and was used for the control force

group. Spring B delivers 0.2 grams of force

when closed to $7 \mathrm{~mm}$. Spring $C$ will provide

0.6 grams of tension when closed to $7 \mathrm{~mm}$.

Note the low load/deflection rate of

approximately $0.01 \mathrm{~g} / \mathrm{mm}$. 


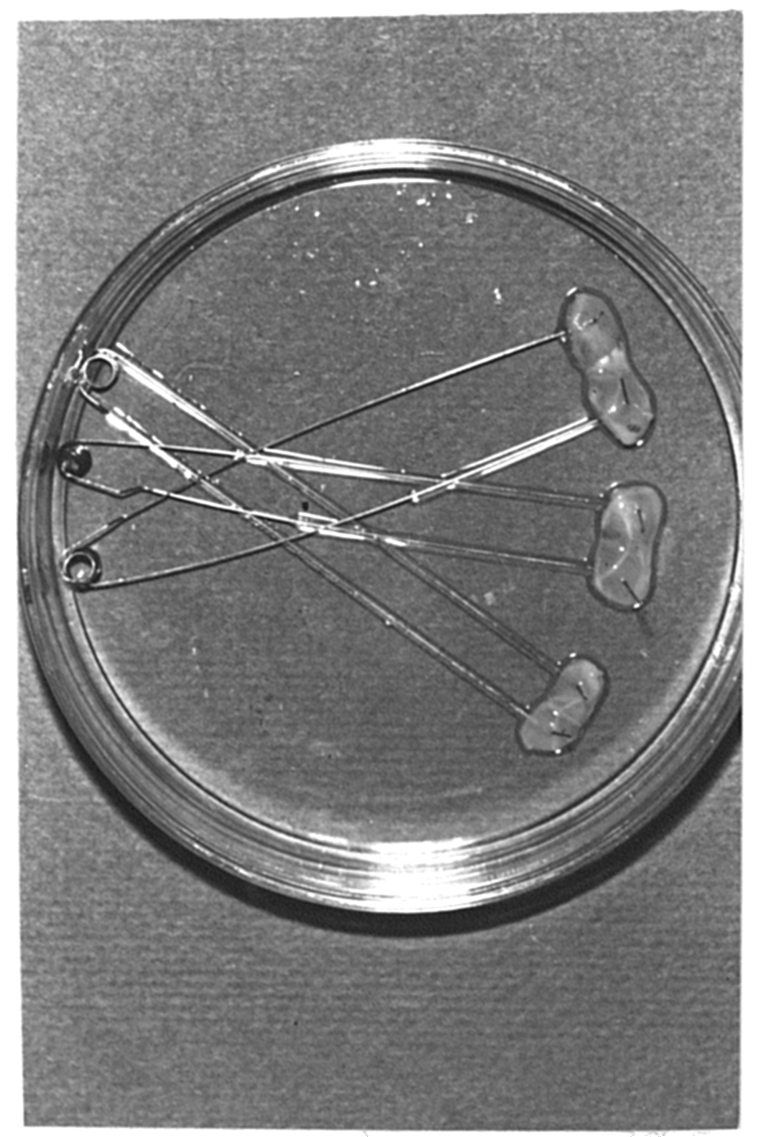

$0.6 \mathrm{~g}$

$0.2 \mathrm{~g}$.

Og. 
Figure 4.

For each force duration group two culture

dishes were used, each containing the three

force groups as shown have been incubated

with $0.6,0.2$ and 0 grams of force from

top to bottom for 6 hours. Note large

amount of stretching shown for the 0.6

gram force on the top as compared to the

small amount for 0.2 grams. No separation

is seen in the control on the bottom. 


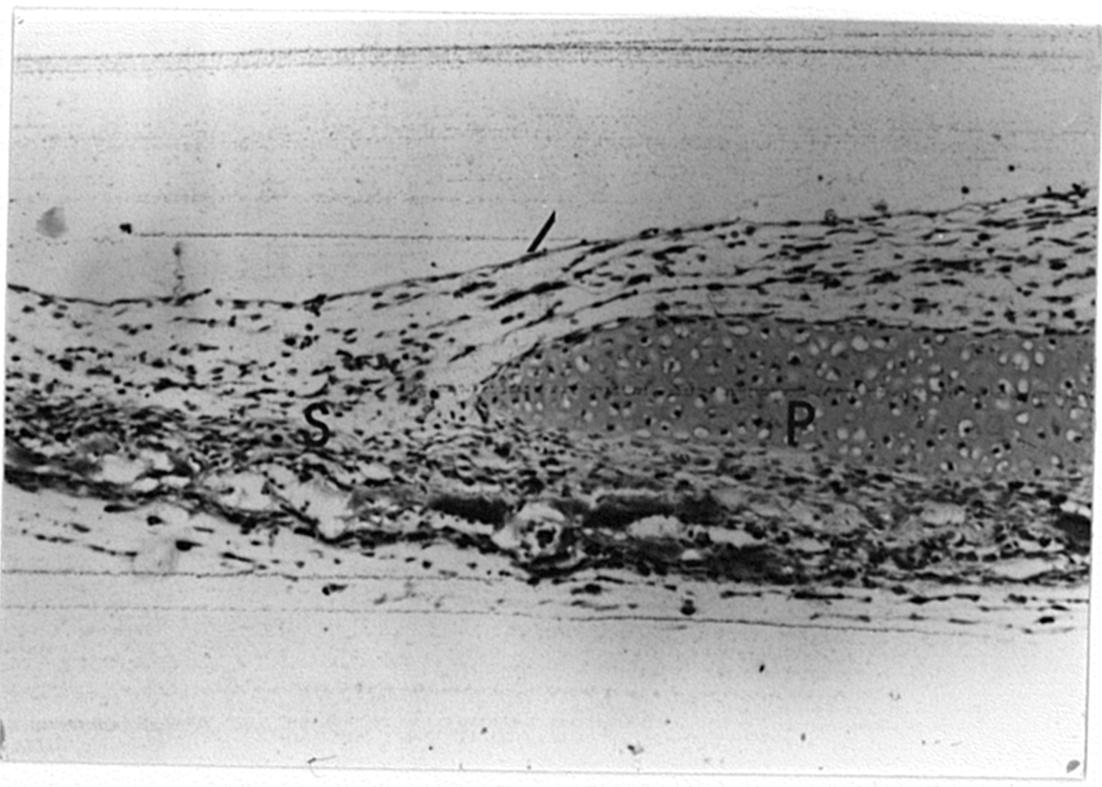


Figure 5. The region of the suture adjacent to the parietal is shown. Note parietal bone and periosteum on the right and suture on the left. Dense labelling is often seen near the bone suture interface. Autoradiography and hematoxyl in and eosin stain.

S - suture, P - parietal bone. 

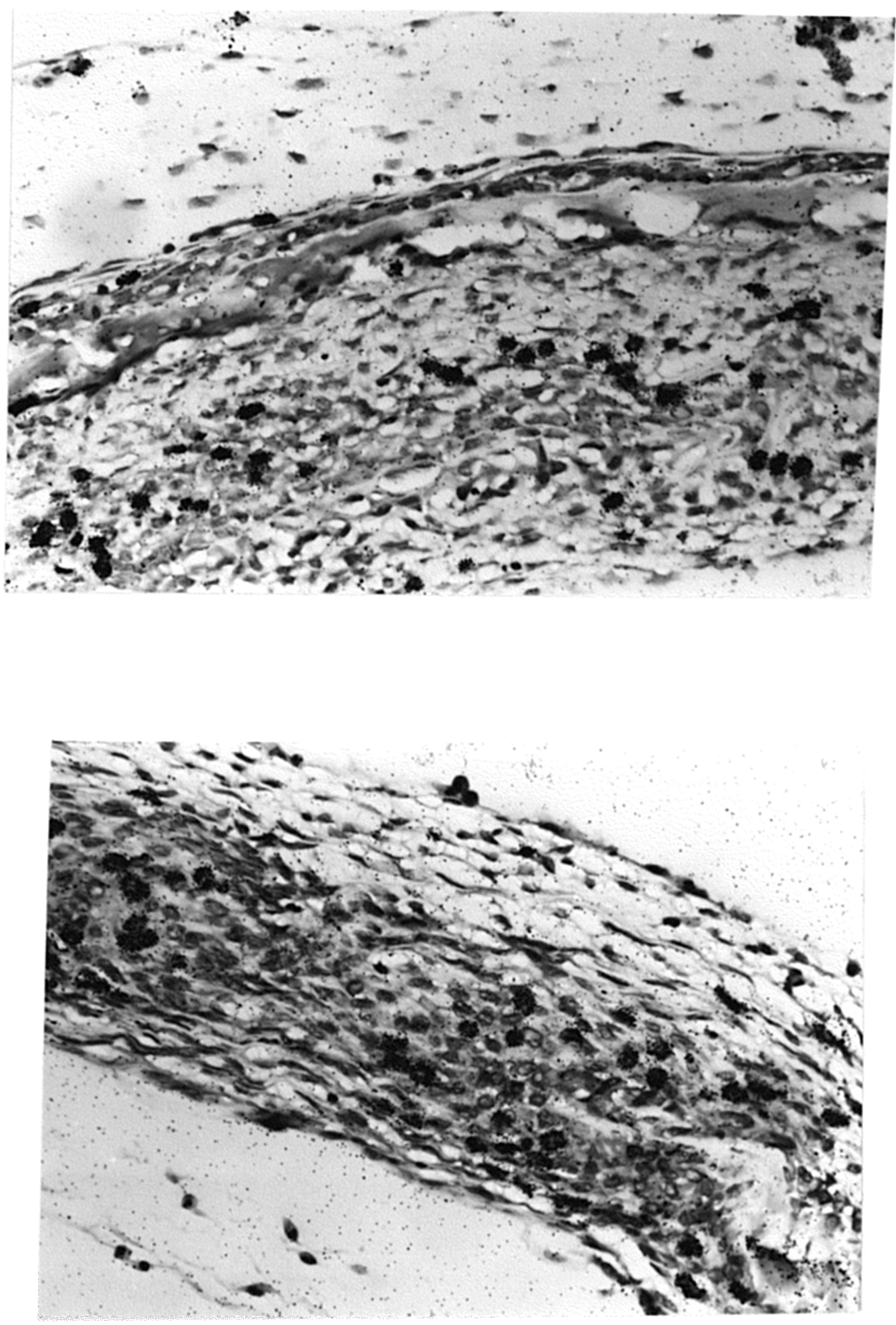
Figures $6 \& 7$ Two sections from the middle area of the suture are shown from explants which were incubated for 5 hours with 0.2 grams of tension. These illustrate a relatively high labelling index. Autoradiography and hematoxylin and eosin stain. 


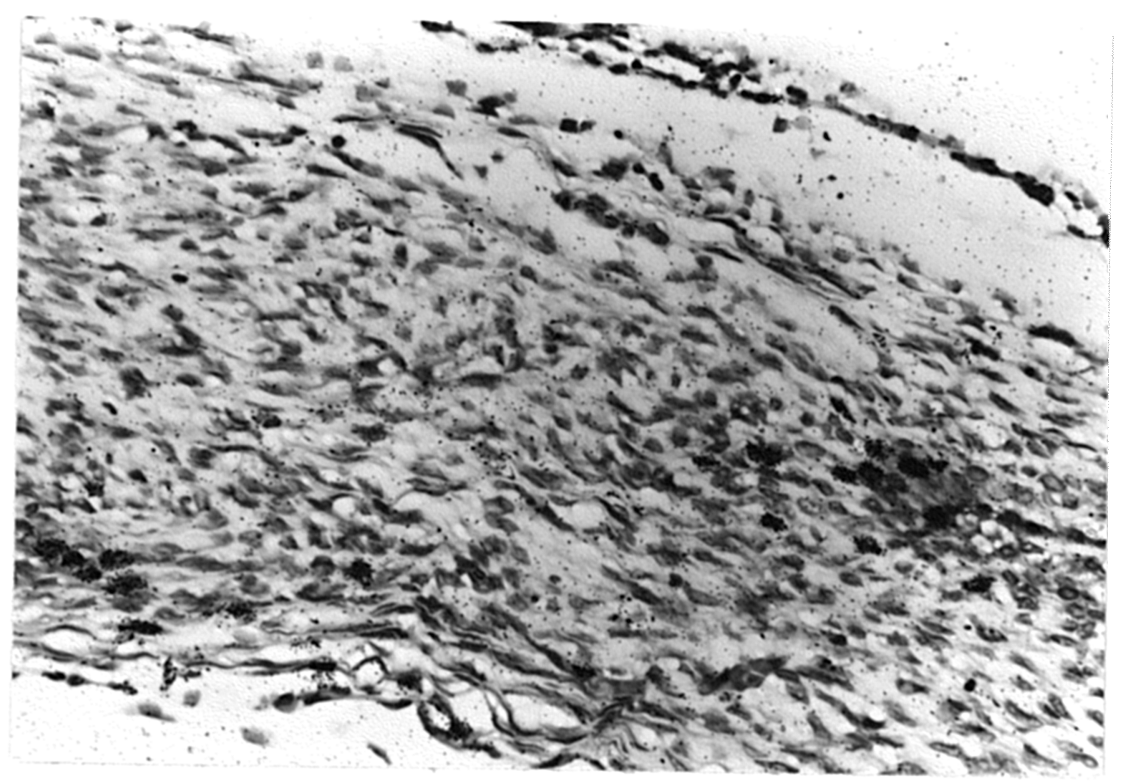


Figure 8

This suture tissue shows a relatively low

percentage of labelled cells as seen after

11 hours of incubation while $0.6 \mathrm{~g}$. of

force was applied. Autoradiography and

hematoxylin and eosin stain. 
FIGURE 9

\section{LABELLING INDEX AS A FUNCTION OF STRAIN}

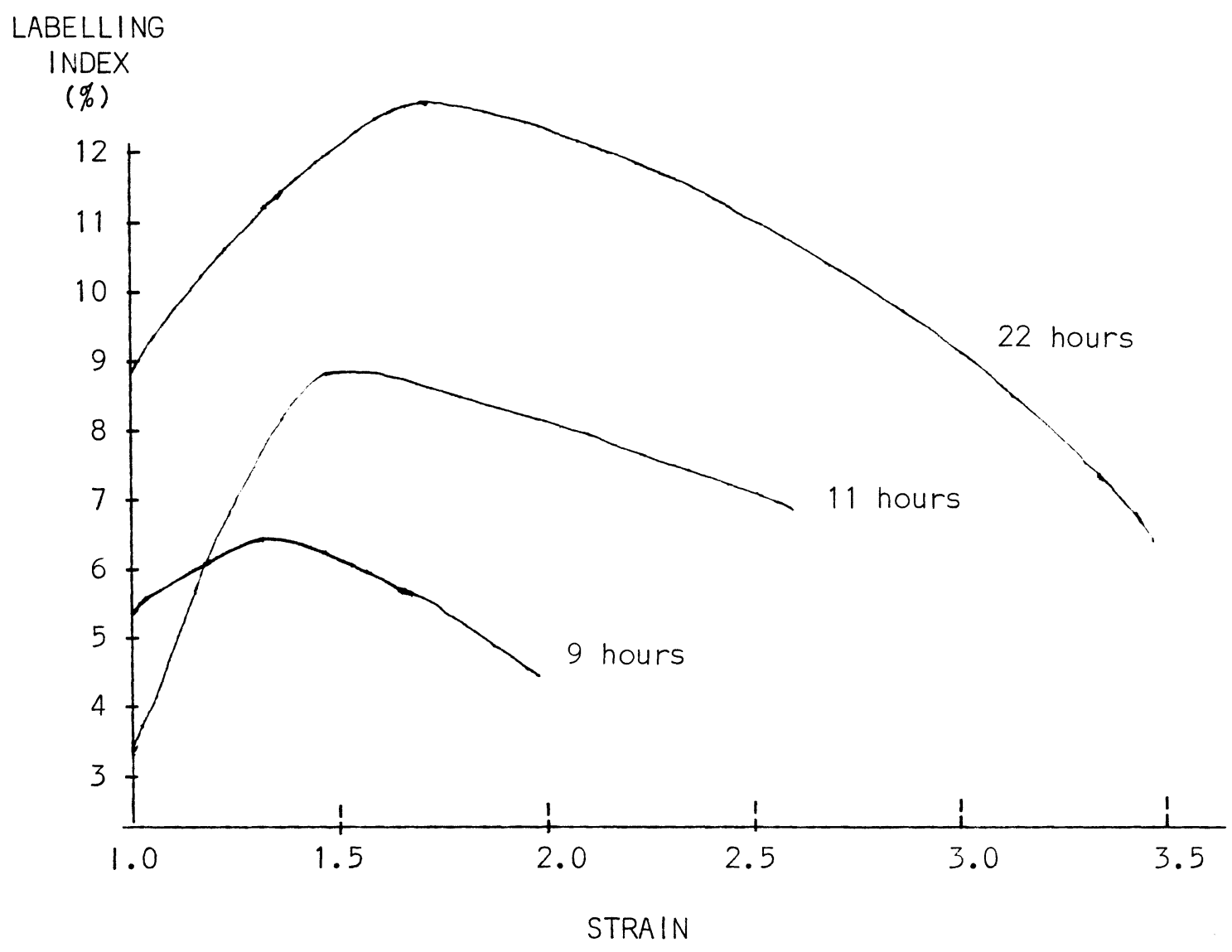




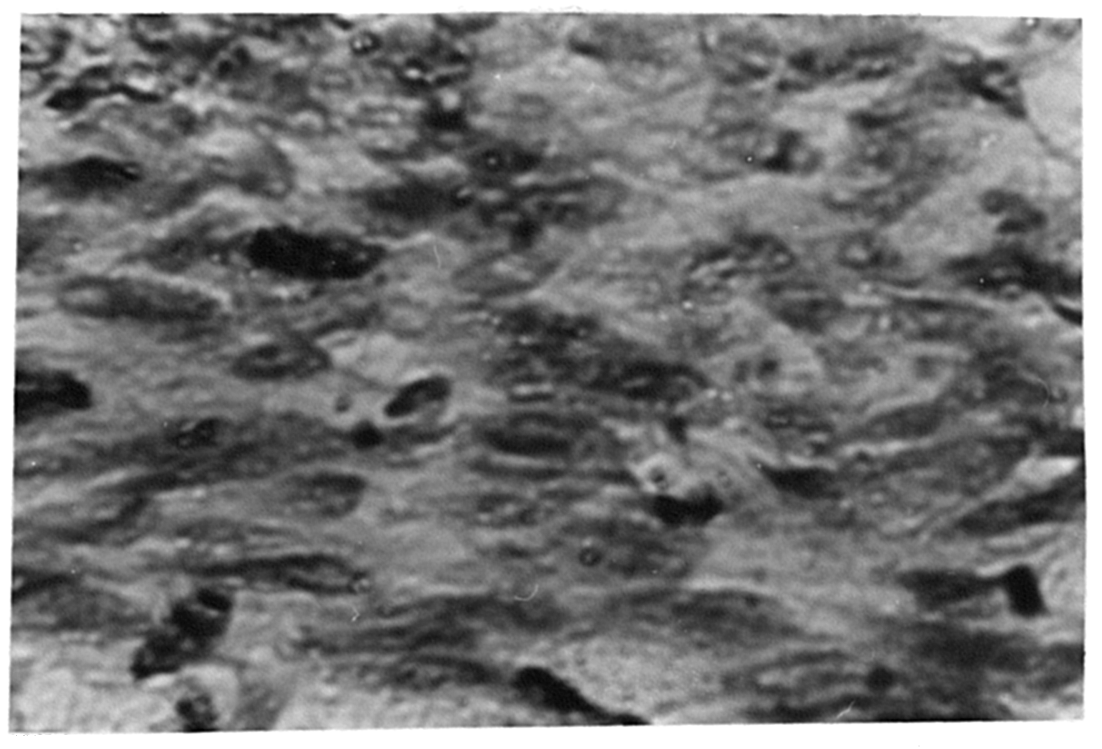


Figure 10 Fibroblast-like cells with characteristic fusiform cell and nucleus shape. Orientation is perpendicular to long axis of the bone suture interface. These more mature cells were associated with a lower labelling index. Fibroblasts were most noticeable in the $0.6 \mathrm{~g}$. group after 11 hours of incubation. Autoradiography and hematoxylin and eosin stain. 


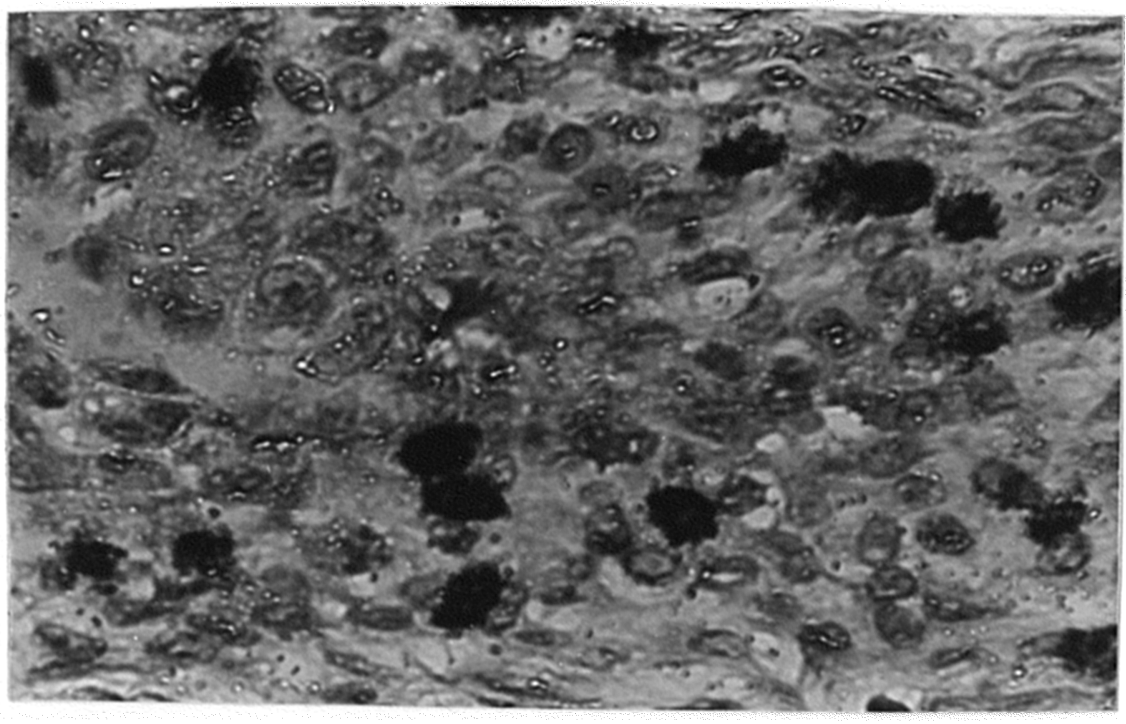




\section{Figure II Undifferentiated messenchymal cells. These cells and their nuclei are spheroid in shape. Cell density is great and the labelling index for these immature cells is typically high. Autoradiography and hema- toxylin and eosin stain.}




\section{REFERENCES}

1. Isaacson, R. and Zimring, J.: Forces produced during rapid maxillary expansion, Angle Orthod., 35:178, 1965.

2. Murray, J. and Cleall, J.F.: Early tissue response to rapid maxillary expansion in the midpalatal suture of the rhesus monkey., J. Dent. Res. 50: 1654, 1971.

3. Nanda, R.: Protraction of maxilla in rhesus monkeys by controlled extraoral forces. Am. J. Orthod. 74:|2|-|4|, 1978.

4. Hinrichsen, G. J. and Storey, E.: Effect of force on bone and bones. Angle Orthod. 38:155-165, 1968.

5. Kambar, T.: Dentofacial changes produced by extraoral forward force in Macaca irus, Am. J. Orthod. 71:249, 1977.

6. Jackson, G.; Kokich, V. and Shipiro, R.: Experimental and post-experiment response to anteriorly directed extraoral force in young Macaca nemestrina. Am. J. Orthod. 75:318-333, 1979.

7. Meikle, M., Reynolds, J., Sellers, A. and Dingle, J.: Rabbit cranial sutures in vitro: a new experimental model for studying the responses of fibrous joints to mechanical stress. Calcif. Tissue Int. 28:137-144, 1979.

8. Meikle, M., Sellers, A. and Reynolds, J.: Effect of tensile mechanical stress on the synthesis of metalloprotein uses by rabbit coronal sutures in vitro. Cal. Tissue Int. 30:77-82, 1980.

9. Baumrind., and Buck, D.L.: Rate changes in cell replication and protein synthesis in the periodontal I igament incident to tooth movement. Am. J. Orthod., 57:109-121, 1970.

10. Roberts, W.E. and Jee, W.S.S.: Cell kinetics of orthodontically stimulated and non-stimulated periodontal ligament in the rat. Archs. Oral Biol., 19:17,21, 1974.

11. Yee, J.A., Kimmel, D.B. and Jee, W.S.S.: Periodontal ligament cell kinetics following orthodontic tooth movement. Cell Tissue Kinet., 9:293-304, 1976.

12. Roberts, W. E. and Case, D.C.: Cell kinetics of orthodontically stimulated osteogenesis. Calc. Tiss. Res. 20 (Suppl); 439-441, 1977. 
13. Baumrind S.: A reconsideration of the property of the pressure-tension hypothesis, Am. J. Orthod. 55:12-21, 1969.

14. Macapanpan, L., Weinman, J.P. and Brodie, A.G.: Early tissue changes following tooth movement in rats, Angle Orthod. 24: $79-95,1954$.

15. Waldo, C.M.: Method of the study of tissue response to tooth movement, J. Dent. Res. 32:690, 1953.

16. Waldo, C.M. and Rothblatt, J.M.: Histologic response to tooth movement in the laboratory rat, J. Dent. Res. 33:481$487,1954$.

17. Badell, M.D.: An evaluation of extraoral combined high pull traction and cervical traction to the maxilla, Am. J. Orthod. $69: 431-446,1976$.

18. Yee, J.A.: Response of periodontal ligament cells to orthodontic force: Ultrastructural identification of proliferating fibroblasts, Anat. Res. 194: 603-614, 1979.

19. Moffett, B.C.: Remodeling of the craniofacial articulation by various orthodontic appliances in rhesus monkeys. Trans. Eur. Orthod. Soc., 207-216, 1971.

20. Storey, E.: Growth and remodeling of bone and bones, Am. J. Orthod. 62:142-165, 1972.

21. Norton, L.A., Rodan, G.A. and Bourret, L.A.: Epiphyseal cartilage $C$ AMP changes produced by electrial and mechanical perturbations, Clinical Orthopaedic and Related Research. $124: 59-68,1977$.

22. Rodan, G.A., Bourret, L.A., Harvey, A., Mensi, T.: 3'5' Cyclic AMP and $3^{\prime} 5^{\prime}$ - cyclic GMP: Mediators of the mechanical effects on bone remodeling, Science 189:467-469, 1975.

23. Harell, A., Dekel, S., Binderman, 1.: Biochemical effect of mechanical stress on cultured bone cells, Calcif. Tissue Res. 22:202-207, 1977.

24. Pritchard, J.J., Scott, J.H. and Girgis, R.G.: Structure and development of craniofacial sutures, J. Anat. 90:73, 1956.

25. Weinmann, J. and Sicher, H.: Bone and Bones, Second Ed. Henry Kimpton, 1965. 
CONCLUSION

An understanding of the biological basis of connective tissue response to force is necessary to rationally prescribe dentofacial orthopedic appliances. Clinical and in vivo experimental studies have had difficulty addressing basic biological questions regarding tissue response due to the complexity of the craniofacial structures. The in vivo model presented removes the problem of a complicated macro and micro suture anatomy. Additionally, the model removes the influence of structures outside the suture on the applied force. The force system is also simplified allowing for control and measurement of all the force variables (duration, magnitude, constancy, point of application and direction). Thus, the model allows investigation of the relationship of the change in a particular force system variable on a specific aspect of the tissue response.

This study suggested that tensile force increases messenchymal cell proliferation (as measured by $3 \mathrm{H}$-thymidine uptake) in suture tissue, but that increasing force magnitude beyond some level $(0.2$ grams in this system) may diminish that response. No definitive conclusions were made regarding the relation of force duration to thymidine uptake.

Similarities between suture tissue and periodontal ligament(PDL) suggests that findings derived from this model system may have implications for understanding the biologic basis of tooth movement as well as the biologic basis of facial orthopedics. Also, since growth is partially directed by forces generated from surrounding 
tissues and function, the understanding suture response to applied forces may contribute to a clearer picture of facial growth and its regulation.

The goal of this model is to describe the biologic response to force and to predict tissue response to force in this and other models. The applicability of the model to predicting response in other models would be greatly enhanced if the stress produced in the suture were calculated. Future studies are planned to derive stress. Use of stress rather than force magnitude will have greater meaning with regard to comparing with other systems. Stress is derived by dividing force magnitude by the cross-sectional area of the structure to which the force is applied.

Future studies are also planned to increase the time which the cranial explants can be maintained in organ culture and to document their vitality, such as with glucose metabolism testing. Although not presently planned, the model would allow study of nutritional or metabolic effects of connective tissue response to force by modifying the culture media (e.g. vitamins or hormones). 


\section{REFERENCES}

Anderson, A.A.: The protein matrixes of the teeth and periodontium in hamsters: A tritiated proline study, J. Dent. Res. 46 (Supp I. 1): $68-77,1967$.

Badell, M.D.: An evaluation of extraoral combined high pull traction and cervical traction to the maxilla, Am. J. Orthod. $69: 431-446,1976$.

Baer, M.: Patterns of growth of the skull as revealed by vital staining, Hum. Biol. 26:80, 1954.

Baumrind, S.: A reconsideration of the property of the pressuretension hypothesis, Am. J. Orthod. 55:12-21, 1969.

Baumrind, S., and Buck, D.L.: Rate changes in cell replication and protein synthesis in the periodontal ligament incident to tooth movement, Am. J. Orthod., 57:109-121, 1970.

Carneiro, J., and Moraes deFava, R.: Radioautographic visualization of collagen metabolism in periodontal tissue of the mouse, Arch. Oral. Biol. 10:833-845, 1965.

Ciancio, S.C., Neider, M.D., Hazen, S.P.: The principal fibers of the periodontal ligament, Periodontics, 5: 76, 1967.

Crumley, P.J.: Collagen formation in the normal and stressed periodontium, Periodontics. 2: 53-71, 1964.

Diaz, E.: Periodontal ligament collagen response to tooth movement: histochemical and autoradiographic reactions, Amer. J. Orthod., 73: 443-457, 1978.

Engdahl, E.; Ritsila, V. and Vadstromer, L.: Growth potential of cranial suture bone autographs, Parts 1 and 11 . Scand. J. Plast. Reconstr.Surg. 12:119, 1978.

Enlow, D.H.: The Human Face. Harper and Row, New York, 1968.

Harell, A., Dekel, S., Binderman, 1.: Biochemical effect of mechanical stress on cultured bone cells, Calcif. Tissue Res. 22 Suppl.: 202-207, 1977.

Hinrichsen, G. J. and Storey, E.: Effect of force on bone and bones, Angle Orthod. 38: 155-165, 1968.

Isaacson, R., Wood, J., and Ingram, A.: Forces produced by rapid maxillary expansion, Angle Orthod., 34: 256-270, 1964. 
Jackson, G.: Kokich, V. and Shipiro, R.: Experimental and postexperiment response to anteriorly directed extraoral force in young Macaca nemestrina. Am. J. Orthod. 75: 318-333, 1979.

Kambara, T.: Dentofacial changes produced by extraoral forward force in Macaca irus, Am. J. Orthod. 71:249, 1977.

Kameyama, Y.: Aj autoradiographic investigation of the developing rat periodontal membrane, Arch. Oral Biol. 18: 473-480, 1973.

Kameyama, Y.: Autoradiographic study of $3 \mathrm{H}$-proline incorporation by rat periodontal I igament, gingival connective tissue and dental pulp, J. Periodont. Res. 10: 98-102, 1975.

Latham, R.A.: The development, structure and growth pattern of the human mid-palatal suture, A. Anat. 108: 31, 1971.

Lewin, E. and Irwing, J.: An autoradiographic investigation of bone remodelling the rat calvarium in organ culture, Arch. oral. Biol. 15: $769,1970$.

Macapanpan, L.; Meyer, J.; and Weinman, J.: Mitotic activity of fibroblasts after damage of the periodontal membrane of rat molars, J. Periodent. 25: 105-112, 1954.

Macapanpan, L.C., Meyer, J. and Weinmann, J.P.: Mitotic activity of fibroblasts after damage of the periodontal membrane of rat molars, J. Periodont., 25: 105-112, 1954.

Meikle, M.; Reynolds, J., Sellers, A. and Dingle, J.: Rabbit cranial sutures in vitro: a new experimental model for studying the responses of fibrous joints to mechanical stress, Calcif. Tissue Int. 28: 127-144, 1979.

Meikle, M., Sellers, A. and Reynolds, J.: Effect of tensile mechanical stress on the synthesis of metalloprotein uses by rabbit coronal sutures in vitro, Cal. Tissue Int. 30: 77-82, 1980.

Moffett, B.C.: Remodeling of the craniofacial articulation by various orthodontic appliances in rhesus monkeys, Trans. Eur. Orthod. Soc., 207-216, 1971.

Moore, A.: Head growth of the macaque monkey as revealed by staining, embedding and undecalcified sectioning, Am. J. Orthod., 35: 654, 1949.

Moss, M.L.: Experimental alteration of suture area morphology, Anat. Res. 127: 549, 1957.

Moss, M.: The functional matrix in Kraus, B. and Riedel, R. (eds): Vistas in Orthodontics, Philadelphia, Lea and Febiger, 1962. 
Murray, J. and Cleall, J.F.: Early Tissue response to rapid maxillary expansion in the midpalatal suture of the rhesus monkey, J. Dent. Res. 50: 1654, 1971.

Nanda, R.: Protraction of maxilla in rhesus monkeys by controlled extraoral forces, Am. J. Orthod. 74: 121-141, 1978.

Norton, L.A., Rodan, G.A. and Bourret, L.A.: Epiphyseal cartilage C AMP changes produced by electrical and mechanical perturbations, Clinical Orthopaedic and Related Research. 124: 59-68, 1977.

Persson, M.: Structure and growth of facial sutures, Odontologisk Revy 24: 3-146, 1973.

Prahl, B.: Sutural growth. Investigations on the growth mechanism of the coronal suture and its relation to cranial growth in the rat, Dissertation, Univ. of Nymegen, 1968.

Pritchard, J.J., Scott, J.H., and Girgis, R.G.: Structure and development of craniofacial sutures, J. Anat. 90:73, 1956.

Reitan, K.: Biochemical principles and reactions, in Graber, T. and Swain, B., editors: Current orthodontic concepts and techniques, Philadelphia, W. B. Saunders Co., III-229, 1975.

Roberts, W.E. and Case, D.C.: Cell kinetics of orthodontically stimulated osteogenesis, Calc. Tiss. Res. 20 (Suppl): 439-44I, 1977.

Roberts, W. E. and Jee, W.S.S.: Cell kinetics of orthodontically stimulated and non-stimulated periodontal I igament in the rat, Archs. Oral Biol., 19: 17-21, 1974.

Rodan, G.A., Bourret, L.A., Harvey, A., Mensi, T.: $35^{\prime}$ - Cyclic AMP and $3^{\prime} 5^{\prime}$ - cyclic GMP: Mediators of the mechanical effects on bone remodelling, Science 189: 467-469, 1975.

Shackleford, J.M.: Scanning electron microscopy of the dog periodontium, J. Periodontal Res. 6: 45, 1971.

Sicher, H.: The principal fibers of the periodontal membrane, Bur. 55: 2, 1954.

Skougaard, M.R., Levy, B.M., and Simpson, J.: Collagen metabolism in skin an periodontal membrane of the marmoset, Scand. J. Dent. Res. 78: 256-262, 1970.

Skougaard, M.R., Frandsen, A. and Baker, D.G.: Collagen metabol ism of skin and periodontal membrane in the squirrel monkey, Scand. J. Dent. Res. 78: 374-377, 1970. 
Stallard, R.E.: The utilization of ${ }^{3} \mathrm{H}$-proline by the connective tissue elements of the periodontium, Periodontics 1: 185-188, 1963.

Storey, E.: Growth and remodeling of bone and bones, Am. J. Orthod. 62: $142-165,1972$.

Waldo, C.M.: Method of the study of tissue response to tooth movement, J. Dent. Res. 32:690, 1953.

Waldo, D.M., and Rothblatt, J.M.: Histologic response to tooth movement in the laboratory rat, J. Dent. Res., 33: 481-486, 1954.

Watanabe, M., Laskin, D.M. and Brodie, A.G.: The effect of autotransplantation on growth of the zygomatico-maxillary suture, Amer. J. Anat. 100: 319, 1957.

Weinmann, J. and Sicher, H.: Bone and Bones, Second Ed., Henry Kimpton, 1965.

Yee, J.: Response of periodontal I igament cells to orthodontic force: ultrastructural identification of proliferating fibroblasts, Anat. Res. 194: 603-614, 1976.

Yee, J.A., Kimmel, D.B. and Jee, W.S.S.: Periodontal ligament cell kinetics following orthodontic tooth movement, Cell Tissue Kinet., 9: 293-304, 1976.

Zaki, A. E. and Van Huysen, G.: Histology of the periodontium following tooth movement, J. Dent. Res., 42: 1373-1379, 1968.

Zimring, J. and Isaacson, R.: Forces produced by rapid maxillary expansion, Angle Orthod., 35: 178-186, 1965.

Zwarych, P.D., Quigley, M.B.: The intermediate plexus of the periodontal ligament: History and further observations, J. Dent. Res. 33:383, 1965. 